\title{
Collaborative Consumption And Sustainability: A Discursive Analysis Of Consumer Representations And Collaborative Website Narratives
}

\author{
Anne-Sophie Binninger, NEOMA Business School, France \\ Nacima Ourahmoune, NEOMA Business School, France \\ Isabelle Robert, University Lille Nord de France-SKEMA Business School, France
}

\begin{abstract}
In this article, the authors analyze the collaborative consumption model and its contribution to sustainable consumption. Indeed, collaborative consumption is considered as an alternative, ecological consumption mode (Bostman \& Rogers, 2011), but previous research has no yet deeply explored to what extent it contributes the sustainable scheme and values. The study therefore investigates both the producer side (collaborative websites) and consumer side (blog participants) to decipher how sustainable ideals are shaped in this context and how consumers attend to them. Six segments of consumers have been identified which can help marketing and sustainable levers better frame their offer.
\end{abstract}

Keywords: Collaborative Consumption; Sustainable Consumption; Access-Based Consumption; Sharing

\section{INTRODUCTION}

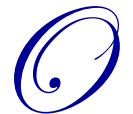

ver the last decade, markets have changed significantly in terms of our relationship to goods, leading to other forms of acquisition and consumption than via possession (Rifkin, 2000, Lovelock and Gummeson 2004, Mont, 2002, Giesler 2006, Chen, 2009, Belk, 2010, Gansky 2010; Bostman \& Rogers 2011, Bardhi \& Eckhardt 2012,).

So-called collaborative consumption (Felson \& Spaeth, 1978) renews consumption logics through mutualizing, exchanging, bartering or sharing products. It is considered as "a socioeconomic groundswell that will transform the way companies think about their value propositions - and the way people fulfill their needs" (Bostman and Rogers, 2010, p.30). It places the use of goods at the heart of the debate over the importance of individual ownership (Bell, 1976, Bauman, 2000, 2007, Bardhi and al., 2012) making it even more important to achieve indepth understanding of the values that guide consumer practices and market supply, particularly on line.

\section{Research Aim}

In this article, we analyze the collaborative consumption model and its contribution to sustainable consumption. Indeed, collaborative consumption is considered as an alternative, ecological consumption mode (Bostman \& Rogers, 2011), but previous research has no yet deeply explored to what extant it contributes the sustainable scheme and values. The study therefore investigates both the producer side (collaborative websites) and consumer side (blog participants) to decipher how sustainable ideals are shaped in this context and how consumers attend to them. 


\section{Assumptions Of The Paper}

In its original form, collaborative consumption is considered as a way to advance towards more sustainable consumption (Chen 2009; Gansky 2010; Ozanne and Ozanne 2011, Bostman and Rogers, 2011). Paradoxically, recent work concludes that it does not necessarily exhibit these qualities (Bardhi and Eckart, 2012). The deep link between sustainable values and collaborative consumption is a neglected research area.

In this article, we examine the collaborative consumption model and attempt to identify its relationship with sustainable consumption. We consider that this relationship is more complex than it appears, both from the point of view of key players and from that of consumers.

\section{Research Question}

The main aim of our research is to identify the marketplace discursive logics that structure the relationship between collaborative consumption and sustainable values. Our research highlights the congruence and contradictions that underlie this relationship. More specifically, we attempt to answer the following questions:

1) How do consumers make sense of their use of collaborative consumption websites, especially with regard to the sustainable dimension promoted via these online platforms

2) How do collaborative websites convey sustainable discourses through their contents and functions?

To achieve this goal we use a qualitative study to reveal the deep meanings contained in the narratives of 46 collaborative sites in France and the UK and the representations of consumers involved in the two most active blogs in France.

\section{Originality Of The Paper}

The paper contributes to a recent stream of research in marketing that investigates collaborative consumption as a complex business phenomenon especially in the Consumer Culture Theory field (Giesler 2006, Chen, 2009, Belk, 2010, Gansky 2010; Bardhi \& Eckhardt 2012). The paper tries to go further in capturing the interconnections between the sustainable prism and collaborative consumption. Taking a discursive perspective we offer to tackle the two sides of the market (producer, consumer) and we shed light on the ambiguous relations between the constructs and their theoretical and business implications.

This research analyses the links between collaborative consumption and sustainable consumption based on the theoretical categorization proposed by Bostman and Rogers $(2010,2011)$. The authors propose an under-used approach: the multi-site research.

The article by connecting sustainability with the emerging so-called collaborative consumption offers theoretical and managerial insights to address the lack of integration of the sustainable values into consumption practice as evidenced by previous research (Kilbourne, 2010, Kotler, 2011, McDonagh et al, 2012).

More specifically, the managerial contribution of our article lies in the fact that it demonstrates the possibility of segmenting consumers who use collaborative sites, and for collaborative websites to adjust their positioning depending on their primary targets.

The remainder of the paper is organized in the following manner. The next section reviews the literature concerning the emergence of the concept of collaborative consumption and its linkages with sustainability. Next, a methodology section addresses the data collecting process and the analysis method followed by the results section. A discussion of the findings and some managerial implications close out the final section. 


\section{THEORETICAL BACKGROUND}

\section{The Emergence Of Collaborative Consumption}

Felson and Spaeth coined the term collaborative consumption in 1978. The authors originally described it as "events in which one or more persons consume economic goods or services in the process of engaging in joint activities with one or more others" (p. 614). The concept was still an emerging one at the beginning of the 2000s, but the development of internet and of collaborative techniques through the Web 2.0 saw a resurgence in consumption behavior focusing on access, exchange and sharing goods and services. Bostman and Rogers (2011) called this collaborative consumption. In this context, use is more important than individual possession. Sharing, lending or renting a good contributes to improve the intensity of its use and facilitates direct exchange between individuals, particularly via Internet. From a local, direct perspective, collaborative consumption can result in people giving up their ownership rights over objects in exchanges based on bartering or giving. When it works via the market and is based on the sale of usage, it is close to access-based consumption, defined by Bardhi and Eckhardt (2012: 881) as "transactions that may be market mediated in which no transfer of ownership takes place." The structural difference from traditional consumption lies at the level of the presentation of the proposed transaction.

This new form of consumption, inseparable from the collaborative spirit of Internet, uses the web as a "weapon of mass collaboration," but its objective is to generate action in the real world ("using the internet to get off the internet") (Bostman \& Rogers, 2011). The validity of the model resides in the benefits of using goods rather than owning them, and on the possible economic, spatial and temporal gains possible. Furthermore, according to these authors (2011: xvii), "these systems offer significant environmental advantages by improving use efficiency, reducing waste, encouraging the development of better products and by absorbing the surplus created by overproduction and overconsumption."

To facilitate the emergence of this new form of collaboration, they identify four principles: 1) the principle of critical mass, which is a necessary condition to ensure the sustainability of the model; it presupposes that the number of participants in the exchanges is large enough to satisfy consumer needs in terms of choice, 2) sharing excess capacity in goods ("the power of idling capacity"), 3) the belief in the possibility of common pool resource management inspired by the work of Ostrom (2010) and finally, 4) mutual trust, which is a key success factor for systems of exchange and "disintermediated" distribution.

Collaborative consumption is made up of numerous practices due to the nature of the possible relations between the actors (sharing, rental, donations, barter...) and to the types of goods exchanged, which can be tangible or intangible. Bostman and Rogers (2011) distinguish three major categories:

- "Product Service Systems" (PSS) or sets of products and services for rent or exchange via platforms managed by an intermediary (mobility, DIY, electrical household goods, clothing, toys, childcare products, fashion accessories, luxury products...),

- $\quad$ Redistribution markets: bartering, giving exchange or second-hand sales platforms between individuals (eBay, le Bon Coin, Freecycle, GuestToGuest)

Collaborative lifestyles which include formulas for sharing immaterial resources between individuals, such as space (working space, gardens, parking space, temporary accommodation), skills, time, money (crowd funding). A derivative of this category is joint direct purchasing from the producer, since this requires prior collaboration on the part of the group of consumers to come to an agreement with a farmer or small producer.

\section{The Sustainable Foundations Of Collaborative Consumption}

In their seminal work, Bostman and Rogers (2011) clearly position themselves in a critical attitude towards the consumer society, and in particular towards waste, the boom in disposable products (throwaway living), planned product obsolescence, and the clutter of useless goods. They point at the consubstantial dissatisfaction of the society of abundance resulting from the "hedonic treadmill" and evoke the never-ending, never-satisfied escalation of consumption. 
At the same time, although the literature is still in its early stages, many authors agree that collaborative consumption is part of the trend towards alternative, sustainable consumption (Albinsson \& Perera, 2012; Gansky, 2010, Ozanne \& Ozanne, 2011 ; Prothero and al, 2011), since it contests individual consumption modes, overconsumption and seeks to tackle the more general issue of sustainable development.

The notion of sustainable consumption is an ill-defined, "fuzzy concept" (Reisch, 1988), whose geometry is variable given the diversity of the meanings, practices and behaviors that it covers (from ecological, fair trade or organic products to "deconsumption"). It can be defined as consumption that takes account of social and environmental criteria from a perspective of inter and intra-generational equity (Jackson \& Michaelis, 2003, Lush et $\mathrm{al}, 2011$ ). Prothero and $a l$ (2011) consider that collaborative consumption, through its intrinsic values, questions the nature of consumption: "by shifting the paradigm away from individual ownership to collectivity and sharing, less demand for consumer goods may give way to a new economy that could help take on problems such as pollution and excessive energy usage." (P.36).

Objects have shaped individual identity for many years; they reveal their owners' values, personal history, are extensions of their owners' ego and highlight their personality (Belk, 1988, Richins, 1994). They are also social markers, revealing social status or belongingness (Bourdieu, 1979) and contribute de facto to the expression of the individual's social identity. Property is also considered as "symbolic receptacles of our memory" (Scholl, 2006). Possession is a characteristic of independence and freedom (Kleine and al., 1995). Ownership is highly conditioned by the symbolic contents of the goods but also by the imaginative world they generate.

Although collaborative consumption seems to be part of the sustainable viewpoint, no previous research has formally demonstrated the reality of this fact, particularly in the context of consumers and the discourse of the sites themselves. Our research is therefore founded on two questions:

- How do consumers make sense of their use of collaborative consumption websites, especially with regard to the sustainable dimension promoted via these online platforms?

- $\quad$ How do collaborative websites convey sustainable discourses through their contents and functions?

These questions will help us to better untangle the potential market segmentation and brand positioning related to collaborative consumption, hence addressing a gap in the literature whilst helping managers to better frame their offer.

First, we present our methodological approach. Then we identify the major discursive drivers of this form of consumption. Finally, we will discuss the results focusing on the links that exist between collaborative consumption and sustainable consumption and they can be leveraged for segmentation and brand positioning purposes.

\section{METHODOLOGY}

Given our research questions that investigate the deep meanings behind discursive representations by consumers and collaborative websites as regard the sustainable ideals, a qualitative study is appropriate. Given our interest in on-line communities and websites netnography - a method specifically designed to study cultures and communities online (Kozinets, 2010) - is relevant. To address our research questions an extensive observation of the two most active consumer blogs in France and an investigation of 46 collaborative websites help identify the key representations of sustainability conveyed by consumers and by prominent collaborative consumption websites.

We specify hereafter our procedures for data selection, analysis and interpretation, which match the guidelines provided by Kozinets (2010) to investigate on-line consumption phenomena.

\section{Criteria for Data selection}

Flyvbjerg's critical case study methodology (e.g., 1991, 2006) recommends selecting case studies that represent particular interest and strategic content in relation to the investigated themes (see Spais, 2011 for an application to research in marketing). 
We selected collaborative consumption websites in France and the UK using the criteria of Bostman and Rogers (2011) for redistribution sites, sites recommending collaborative lifestyles and product service systems (PSS) to embrace the various strategic logics behind the 'making' of collaborative consumption by the marketplace actors. We try to identify here the various business practices and discourses that emerge from recent collaborative trend. By seeking qualitative diversity, we enrich the interpretation of the phenomenon under study. We believe this helps better unpack the diverse strategic claims made by the websites to target consumers and how this impacts their discourses as regard sustainable values.

Table 1 lists the 46 sites studied over a period of 28 months (February 2012 - June 2014). An extensive period of investigation allows us to perceive change and adopt a dynamic vision of an emerging business phenomenon. A longitudinal perspective serves a deep understanding of the websites' complex ideological positioning. This period was necessarily shorter for recently created sites such as Partage ton frigo, I lok you, Le bœuf français.

Our study also identifies consumers discourses related to collaborative consumption and specifically how they relate to sustainable values. The two blogs selected are the most active in France, which is an important criterion for an appropriate study of on-line communities from a sociocultural standpoint (Kozinets, 2010). Their objectives are to disseminate information and to encourage discussion among the members of a virtual community that supports and/or is aware of this new form of consumption (c.f. table 1). The forum enables members to debate different topics linked to the information published on the site. Focusing on those two very active blogs helps the authors make sense of the consumers' diverse representations and practices regarding the themes investigated (e.g. motivation to participate in collaborative consumption, representations of this practice, relationship between collaborative consumption and sustainable consumption, specific and innovative use of collaborative consumption...).

\section{Analysis}

Using the principle of netnography (Kozinets, 2002), the authors took part in the forums, observing the articles posted over the period studied. This enabled the researchers to select a varied, contrasting set of articles written by the community (messages posted on the discussion forum, chat-room conversations) (Lincoln \& Guba, 1985). A file containing all the data related to the websites and blogs (screenshots, images, articles, messages) totaling 560 pages made up our corpus to analyze collaborative consumer motivations and their alignment with sustainable values.

First the three authors analyzed the material collected separately; then together. One of the authors is extremely keen on this type of website and very involved in sustainable causes. The two other authors provided perspective and different points of view, as they are less engaged in the field, thus ensuring analytical distance (Ourahmoune and Ozçaglar-Toulouse, 2012). From the horizontal and vertical manual thematic analysis of all of the material collected, categories of meaning emerged, leading to a high level of reliability between the coders. The findings represent the authors' negotiated understanding of the themes that emerged. For this article the results concentrate on: purchasing motivations for consumers on collaborative sites, the meanings behind these renewed consumption behaviors and their consistency with sustainable values.

More specifically, for each of the 46 collaborative websites and two blogs, the authors proceeded with three stages to analyze the data.

1. Clarification of the purpose of the website, the identification of diverse discourses represented by each case. We paid specific attention to the motives and goals expressed by the actors, identifying the major values promoted by the websites, the contradictions that may arise from their narratives (individual, collective, instrumental, hedonic, specific to a subset of values linked to sustainability ...).

2. Identification of the in-depth component of each discourse focusing on the signifiers or categories of meanings that emerged (concepts, goals, tools, results) and the signifiers (ergonomics, colors, forms, typography, visuals, rhythms, sounds, colors) that enable the making of a specific discourse on collaborative consumption and their eventual link with sustainability. 
3. Finally, the structure of the available discourses was analyzed by making comparisons and contrasts and by going back and forth between the literature on collaborative consumption and on sustainability and the data to interpret the emerging findings.

In the next section, we detail the major findings of our study focusing on how the deciphering of consumer and business discourses on sustainability in the context of collaborative consumption illuminates a connection between two constructs much neglected in the marketing literature.

Table 1: Data: Collaborative Sites And Blogs Studied

\begin{tabular}{|c|c|}
\hline Collaborative consumption sites and marketplaces studied (46) & Blogs (2) and period of study \\
\hline $\begin{array}{l}\text { Product Service Systems: } \\
\text { Velib' - V’Lille - Autolib' - Buzzar - Zipcar } \\
\text { BlablaCar - Mu by Peugeot - Drivy - Je loue mon camping car } \\
\text { - E-loue - Lokeo - Zilok - Ilokyou - Bricolib -Street Club - } \\
\text { Mon Joujou - Ecojouet - Maman loue - Mon dressing - Ma } \\
\text { bonne amie - Sac De Luxe - La machine du voisin - Baby } \\
\text { plume - La fabrique des lunettes - Partage ton frigo }\end{array}$ & 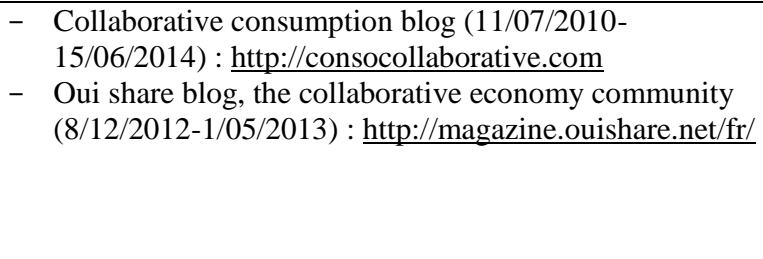 \\
\hline $\begin{array}{l}\text { Redistribution marketplaces: } \\
\text { Vestiaire collective - Videdressing - Freecycle - My Recycle } \\
\text { Stuff - Le comptoir du don -Troc Vestiaire - Homelink - } \\
\text { GuestToGuest- Troc de presse }\end{array}$ & \\
\hline $\begin{array}{l}\text { Collaborative lifestyles (including group purchasing): } \\
\text { Réseau Cocagne - Choux fleurs et pissenlits - Le bœuf } \\
\text { français - La ruche qui dit oui - Campe dans mon jardin - } \\
\text { Plantez chez nous - Bureaux à partager - La ruche - } \\
\text { KissKissBankBank - Babyloan - Yooneed - Accorderie }\end{array}$ & \\
\hline
\end{tabular}

\section{FINDINGS}

\section{Overview Of The Links Between Collaborative And Sustainable Consumption}

To better understand the relationship between collaborative consumption and sustainable consumption, we first present a summary of the data collected from nine sites we consider a representative sample ( 3 per category). We isolate the values conveyed and the nature of the evidence provided. Finally, we identify whether there is a high, medium, low or no agreement between the two. It should be noted that values referring to other dimensions (utilitarian, hedonistic) are not described in detail here. We show that numerous sites declare both collaborative and sustainable values, but to varying degrees. When the site's positioning originates in a critique of the consumer society (admiration for giving, sharing, desire to change society), the links are more natural and the concepts interconnect harmoniously and effectively. Generally, these sites have a code of good conduct or a charter to make these values explicit. In other cases, the agreement remains limited and the two discourses are even disconnected. 
Table 2: Summary Of Data Analysis Of Nine Emblematic Collaborative Consumption Websites Under The Two Themes Studied (Sustainable And Collaborative Narratives)

\begin{tabular}{|c|c|c|c|c|c|}
\hline & \multicolumn{2}{|c|}{ Values Affirmed } & \multicolumn{2}{|c|}{ Evidence } & $\begin{array}{c}\text { Agreement } \\
\text { between } \\
\text { CC \& SC }\end{array}$ \\
\hline \multicolumn{6}{|c|}{ Nature of Model: PPS } \\
\hline Name of Site & Collaborative Discourse & Sustainable Discourse & Ergonomics & Verbatims & \\
\hline Autolib' & $\begin{array}{l}\text { Contribute to making the } \\
\text { city more humane, more } \\
\text { agreeable \& more } \\
\text { friendly, travel more } \\
\text { easily }\end{array}$ & $\begin{array}{l}\text { Ecological mobility; } \\
\text { fewer cars, less } \mathrm{CO} 2 \text {, } \\
\text { easier to breatche in town, } \\
\text { less traffic, zero } \\
\text { emissions... }\end{array}$ & $\begin{array}{l}\text { Colorful design. A } \\
\text { number of simplified } \\
\text { graphic features on } \\
\text { ecology; Simplified } \\
\text { didactic steps "How to do } \\
\text { it"; Ecological discourse } \\
\text { centered on electricity; } \\
\text { Sharing is encouraged via } \\
\text { "sponsoring" labels or } \\
\text { offering a subscription to } \\
\text { a friend... }\end{array}$ & $\begin{array}{l}\text { "With Autolib' and its } \\
100 \% \text { electric Bluecars, } \\
\text { everyone can travel round } \\
\text { town without producing } \\
\text { direct emissions." }\end{array}$ & Medium \\
\hline Ilokyou & $\begin{array}{l}\text { Mutual help, sharing, } \\
\text { collaboration, social } \\
\text { network are key words } \\
\text { in the justification }\end{array}$ & $\begin{array}{l}\text { Struggle against } \\
\text { excessive consumption, } \\
\text { importance of use. } \\
\text { Arguments focus on } \\
\text { sustainability. }\end{array}$ & $\begin{array}{l}\text { A page per need. } \\
\text { Personalisation of need } \\
\text { via filter questions; } \\
\text { Individual stories with } \\
\text { photos ;Written charter } \\
\text { reinforcing the site's } \\
\text { commitments; } \\
\text { Highlighted keywords on } \\
\text { ecology }\end{array}$ & $\begin{array}{l}\text { "Mutual help between } \\
\text { neighbors is the future!" } \\
\text { "Choose one-off use } \\
\text { rather than ownership. It's } \\
\text { cheaper, easier and more } \\
\text { responsible. In a word: it } \\
\text { makes sense!" }\end{array}$ & High \\
\hline \multicolumn{6}{|c|}{ Nature of Model: Redistribution Market-place } \\
\hline Homelink & $\begin{array}{l}\text { Develop a network of } \\
\text { friends }\end{array}$ & N/A & $\begin{array}{l}\text { Site begins by } \\
\text { highlighting } 20 \text { reasons } \\
\text { to exchange } \\
\text { accommodation, } \\
\text { including several linked } \\
\text { to social connections: } \\
\text { photos of people, places, } \\
\text { houses }\end{array}$ & $\begin{array}{l}\text { "When you exchange } \\
\text { houses, you discover not } \\
\text { only other places, but the } \\
\text { very life of the people } \\
\text { who live there .../... You } \\
\text { also benefit from the } \\
\text { kindness and } \\
\text { consideration of the } \\
\text { exchange family, who tell } \\
\text { you all about the region." }\end{array}$ & Inexistent \\
\hline $\begin{array}{l}\text { Le comptoir } \\
\text { du don }\end{array}$ & $\begin{array}{l}\text { Justification based on } \\
\text { sharing and generosity, } \\
\text { recycling, longer } \\
\text { product life, repairs, } \\
\text { waste }\end{array}$ & $\begin{array}{l}\text { Emphasis on three } \\
\text { dimensions of SD: } \\
\text { economic, social and } \\
\text { ecological }\end{array}$ & $\begin{array}{l}\text { Figurative approach } \\
\text { stressing the power of } \\
\text { giving; Some eye- } \\
\text { catching photos linking } \\
\text { ecology and donating }\end{array}$ & $\begin{array}{l}\text { "Le comptoir du don" is a } \\
\text { campaign that concerns } \\
\text { everyone who wants to } \\
\text { create a more humane } \\
\text { world: harmony between } \\
\text { economy and ecology!" } \\
\text { "MORE HUMANE, the } \\
\text { world will be if you give } \\
\text { what you no longer use, or } \\
\text { what is cluttering up your } \\
\text { home." } \\
\text { "MORE ECOLOGICAL, } \\
\text { The world will be because } \\
\text { what you give can still be } \\
\text { useful if it is in good } \\
\text { working order or if it can } \\
\text { be repaired or transformed } \\
\text { depending on what we } \\
\text { need." }\end{array}$ & High \\
\hline $\begin{array}{l}\text { Le troc de } \\
\text { presse }\end{array}$ & $\begin{array}{l}\text { Building closer links } \\
\text { with neighbors }\end{array}$ & Reduction of waste & $\begin{array}{l}\text { Simplified, graphic site; } \\
\text { Eye-catching slogans + } \\
\text { visual highlighting the } \\
\text { site's media links; } 3 \\
\text { "good ideas" clarified and } \\
\text { explained: Economic "I } \\
\text { save money, it's } \\
\text { free", social "I build } \\
\text { relationships", ecological } \\
\text { "I waste less" } \\
\end{array}$ & $\begin{array}{l}\text { "Troc de presse is the first } \\
\text { completely free website } \\
\text { encouraging you to recycle } \\
\text { your newspapers and } \\
\text { magazines intelligently. } \\
\text { Give them a second life by } \\
\text { bartering, exchanging } \\
\text { and/or giving them to your } \\
\text { neighbors..." }\end{array}$ & High \\
\hline
\end{tabular}


(Table 2 continued)

\begin{tabular}{|c|c|c|c|c|c|}
\hline & \multicolumn{2}{|c|}{ Values Affirmed } & \multicolumn{2}{|c|}{ Evidence } & $\begin{array}{c}\text { Agreement } \\
\text { between } \\
\text { CC \& SC }\end{array}$ \\
\hline \multicolumn{6}{|c|}{ Nature Of Model: Collaborative Lifestyles } \\
\hline Name of Site & Collaborative Discourse & Sustainable Discourse & Ergonomics & Verbatims & \\
\hline $\begin{array}{l}\text { Réseau } \\
\text { Cocagne }\end{array}$ & $\begin{array}{l}\text { Solidarity, mutualism } \\
\text { dissemination, } \\
\text { experiment, alternative } \\
\text { society... }\end{array}$ & $\begin{array}{l}\text { Argument focusing on } \\
\text { short distribution circuits, } \\
\text { organic products and food } \\
\text { accessibility }\end{array}$ & $\begin{array}{l}\text { Tasteful design: photos, } \\
\text { landscapes, people in } \\
\text { action, verbatims } \\
\text { Two drop-down menus } \\
\text { entitled: "organic food } \\
\text { baskets" and "social } \\
\text { objectives" } \\
\text { Extensive supporting } \\
\text { information for both. }\end{array}$ & $\begin{array}{l}\text { "You need vegetables, they } \\
\text { need work. Together, let's } \\
\text { grow solidarity." } \\
\text { "Do you want to create a } \\
\text { garden of plenty? Our } \\
\text { Cocagne Network } \\
\text { "dissemination and } \\
\text { development" is here to } \\
\text { help you }\end{array}$ & High \\
\hline $\begin{array}{l}\text { Campe dans } \\
\text { mon jardin }\end{array}$ & $\begin{array}{l}\text { Conviviality and } \\
\text { friendship }\end{array}$ & N/A & $\begin{array}{l}\text { Unattractive site visually } \\
\text { and didactically; Centered } \\
\text { on a map showing the } \\
\text { locations; Undeveloped } \\
\text { argument focusing on } \\
\text { friendship, meeting new } \\
\text { people and security. }\end{array}$ & $\begin{array}{l}\text { "Campedansmonjardin.com } \\
\text { offers campers a convivial } \\
\text { type of camping .../...The } \\
\text { aim of the service is to } \\
\text { connect garden owners with } \\
\text { people looking for } \\
\text { somewhere to camp. }\end{array}$ & Inexistent \\
\hline Babyloan & $\begin{array}{l}\text { Develop a new kind of } \\
\text { solidarity }\end{array}$ & $\begin{array}{l}\text { Mention of the ecological } \\
\text { dimension in certain } \\
\text { projects. }\end{array}$ & $\begin{array}{l}\text { Illustrated hooks with } \\
\text { photos of micro- } \\
\text { entrepreneurs } \\
\text { (personalized } \\
\text { relationships); Didactic } \\
\text { Representation of ways of } \\
\text { making donations and } \\
\text { loans (stages); Use of } \\
\text { updated statistics and } \\
\text { figures to give the system } \\
\text { credibility; Some } \\
\text { ecological projects among } \\
\text { numerous social and } \\
\text { economic ones }\end{array}$ & $\begin{array}{l}\text { "Babyloan chose as its } \\
\text { mission that of defending } \\
\text { and promoting social, } \\
\text { inclusive microfinance, } \\
\text { centered on support for } \\
\text { initiatives by local people." }\end{array}$ & Low \\
\hline
\end{tabular}

The parallel analysis of these sites and of consumer discourses sheds extensive light on the nature of these links. Thus, we find that the meaning given to this form of consumption involves two dimensions: firstly relational and ecological factors, both individual and collective, that lead to new approaches to consumption; secondly multiple, vivid utilitarian and hedonic factors that are part of traditional approaches to consumption. These two facets are closely interrelated, and suggest the possibility of segmenting consumers and of more effective positioning on the part of the players in this market.

\section{The Ecological Trope: An Ambiguous Relation}

First of all we observe that several ecological criteria are strongly highlighted in website sales arguments: reducing the ecological footprint, the carbon footprint, fighting planned obsolescence and waste, reuse and recycling etc.

"So the objects are used more and better, in opposition to the 'throwaway consumption' that many of us are against. Hence, sharing the use of the products is clearly an ecological action." Extract from the site Ilokyou.

«Troc de presse is the first completely free website proposing to recycle your newspapers and magazines intelligently by giving them a second life via bartering, exchange and/or giving them away to your neighbors..." Extract from the site Troc de presse. ${ }^{\text {ii }}$

But this aspect is rarely the first mentioned, and is very often coupled with financial and/or social arguments: 
"Renting toys facilitates dematerialization and reduces the proliferation of waste. It becomes a new way of consuming. It makes you more environmentally responsible, and at the same time increases your purchasing power." Extract from the site Mon joujou iii.

It is therefore established that precise arguments about sustainable development are used on a majority of the sites. This demonstrates that these new sales concepts are based on sustainability, which enables them to distinguish themselves from traditional, less ecological kinds of selling and to target more directly green consumers who are more liable to be attracted by alternative consumption styles (Connolly \& Prothero 2003).

As for consumers, ecological motives are in the minority in the messages and articles they post. They are only expressed by a small segment of consumers, who systematically use them in conjunction with other criteria:"Collaborative consumption has everything you might: it allows you to earn extra income from resources you don't use, it creates new social links between peer-to-peer service users and has the potential to reduce our ecological footprint. In other words, in every sense or the terms, the sharing economy is a sustainable economy." (Arthur, message posted on 7 August 2013, collaborative consumption blog).

This observation about collaborative consumption is in line with recent research showing that despite increasing awareness of the environment by individuals (European Commission Eurobaromètre 2008, Chang, 2011), consumption behavior motivated by ecological criteria remains marginal or secondary (Markkula et al, 2012, Gleim et al, 2013).

\section{Social Stickiness: The Predominant Motivation}

The sharing of property is a key element of collaborative consumption. It supposes that people's relationship to property and attachment to objects is changing, through two key notions, sharing and access: "Isn't it great to widen your circle of friends just by exchanging houses? Message posted by Gaby on the site Homelink. ${ }^{\text {iv }}$

These two notions can be found both in consumer discourses and in the sales arguments used on the sites:

"First of all, the experience of 'Your neighbor's Machine' is nothing like the experience of going to the launderette. Meeting someone nice and drinking a coffee together is much more interesting than watching your washing go round" message posted by Jean-Philippe on 21 March 2012, from the collaborative consumption blog.

The creation of social links (by meeting new people) seems to be one of the main motivations.

"I am convinced that when a car is used for car sharing it's a different color, it gives off an aura that's good for everyone, so much sharing, so much happiness, listening to others, fits of laughter, we embrace each other when we set off like old well-loved acquaintances, and it's the same when we arrive, wishing each other all the very best. Imagine if all the cars were lit up like that, the roads would be much prettier." Message posted by Marie on 16 October 2013 on the site BlablaCar.

Thus, collaborative consumption practices give objects distinct value based on "their ability to express, to convey, to feed social relations" (Godbout, 1992: 245).

More than sharing and experience, this can sometimes go as far as becoming a member of a community sharing the same values, whether this community develops out of consumers' experience or set in motion by the sites themselves:

"Ever thought how much more social, helpful and rewarding it would be if you could easily talk, share and plan with your street? We did too - so we created Streetclub to connect you \& your neighbors with a private 'on-line community noticeboard' that's easy and safe to use. Why not start a club, talk, share and plan with those around you, and bring back a sense of community today!" extract from the site Streetclubv. 
"I really needed a ladder to clear out my gutters. It was great to be able to borrow one from my neighbors, rather than having to buy one - and I even got an offer of some help too!" message posted by a user on 21 December 2013 on the site Streetclub.

We may note that this community aspect differs depending on the procedure proposed by the site. When the use of the good is shared by individuals simultaneously (car sharing for example), the search for social links appears to predominate. "Car sharing is a dash of adventure, a whole lot of meetings of every kind but always friendly. Car sharing is a reprieve for the planet. Car sharing is landscapes, the open road and then a rainbow, a flash of lightning, a sunset. Car sharing is a community in the noblest sense. Virgile, message posted on 31 May 2011 on the site BlablaCar.

This need is also dominant when access to the good is via a marketplace where individuals meet physically (sites such as la machine du voisin, je loue mon camping car, Bricolib...).

But when access to the good is based as traditionally on anonymity, both personal and spatial, the community aspect is relatively invisible, or may even be rejected when it is intentionally put forward (for example the site Zipcar).

\section{Changes In Relation To Objects And To Consumption}

A third phenomenon is clearly apparent, concerning the acquisition and accumulation of goods that are no longer the only method of consumption or the only way to establish a link with an object:

"One of the advantages of using Freecycle is that it encourages us to get rid of things bought on impulse that we don't need any more, and encourages everyone to think about the community as a whole" Extract from the site Freecycle. ${ }^{\text {vi }}$

"Of course there's the financial crisis, that isn't conducive to buying and forces you to look for alternative solutions. But the desire for possession is also wearing away." (Eric, message posted on 26 October 2010 on the collaborative consumption blog.)

We observe then that the conviction that happiness depends on possessions is collapsing. In certain cases, collaborative consumption can become a form of thoughtful resistance symbolizing the desire to escape from the market system or even the economic system:

"My ultimate aim in life? Never to have to use a supermarket. And I'm almost there!" Testimony by Aurélie, extract from the site La Ruche qui dit oui. ${ }^{\text {vii }}$

"At a time when humanity is facing an identity crisis, when the foundations of our economy are collapsing, when the world is losing its meaning, when interests appear more important than people..., choose to take part with Yooneed in this human adventure, to shine out and help others shine by exchanging your practical and intellectual talents, by putting people at the center of your concerns, and make the dream become reality" extract from the site Yooneed. ${ }^{\text {viii }}$

The choice of using a collaborative consumption site highlights the consumer's desire for independence, and sometimes their resistance to "consumerism" or the dominant consumer culture (Dobscha, 1998).

\section{Collaborative Consumption: New Concept, Classic Utilitarian Foundations}

\section{Utilitarian Motives At The Heart Of Collaborative Consumption}

We note that individual utilitarian or financial motives are preeminent by comparison with social and environmental values. Thus, consumer discourses refer to unstable economic conditions, to the desire for nomadism, more ephemeral lifestyles, growing technological innovation, technological and psychological obsolescence, and to 
a desire for practicality, such as flexible use, ease of use, a reduction in perceived risk. They also highlight the interest of this model as an alternative to storage constraints and clutter (vehicles, bicycles for example).

"Why own your own washing machine, flat-screen TV or computer? What matters is the use you get from them: washing your clothes, watching TV, working or communicating with your computer...! But what also matters is not having to deal with unexpected problems!" Extract from the Lokeo site ${ }^{\mathrm{ix}}$.

"In live in an apartment, so I'm going to be able to change all my children's toys, I will have less to store." message posted by Pascale on 14 January 2012, Monjoujou ${ }^{\mathrm{x}}$.

Similarly, and unsurprisingly, the financial arguments put forward on the sites, as well as the motivations identified on the different blogs appear to be crucial:

"The first advantage in my opinion is the price. From a rental company the prices are less attractive, and if you include the extras (bicycle rack, sheets, crockery, GPS etc.) the bill goes up very fast.../...The owner describes in the ad what he is making available, and the loan of this equipment is not charged to the renter. The owner's price is fixed; you know how much you're paying" Interview with the Guittard family in the blog JeLoueMonCampingCari ${ }^{\mathrm{xi}}$.

"E-loue is a simple, effective Internet platform that lets any individual or professional put their property up for hire or look for things to rent. Their first aim is: increase their purchasing power (the owners as well as the renters) by making savings and earning money" extract from the site Loue.com ${ }^{\mathrm{xii}}$.

These quotes reinforce the idea of the preeminence of economic motives and the search for maximum purchasing power, which are both traditional consumer behaviors and widespread market discourses.

\section{Collaborative Consumption At The Heart Of Hyper-Consumerism}

Apart from the financial aspects, the study reveals a link between simplicity of use and a form of increased desire. The varied and rich data stress the fact that the products are continually renewed (sites for clothing, fashion accessories, electrical household goods...) and the pleasure in having new possessions.

"Renting toys from EcoJouets, means you are certain to get quality toys that you choose from a range of best-sellers. No more hassle with storing them or obsolescence, when your rental period is up just send us back the toys" extract from the site Ecojouet. ${ }^{\text {xii }}$

A form of addictive consumption appears, created by these fun experiences and by this need for novelty, speeding up the cycle of desire:

"I love the concept. No more toys all over the place. Heaven! The children love having new toys every month" message posted by Vanessa on 6 July 2010 on the site Mon joujou ${ }^{\text {xiv }}$.

"With our community, the wardrobes of the world are available to you. Meet fashion lovers from the four corners of the globe, imitate their style, share your enthusiasm and talk about your wishes. Launch your own boutique on internet, find amazing items at irresistible prices, enjoy them for a year and then sell them on to find new gems the year after" extract from the site Vide dressing ${ }^{\mathrm{xv}}$.

By recovering used products and/or circulating goods between individuals constantly, collaborative sites facilitate and encourage the cycle of use - frustration - renewal. The psychological obsolescence caused by the succession of minor modifications in functional and aesthetic terms becomes the cause of the repetitive consumption of goods such as clothes, cars, electrical household goods and so on (Sheth et al, 2011).

By reinforcing the ideology of hyper-consumption through this constant need for renewal (Lipovetsky, 2006), collaborative consumption can also be associated with the idea of aspirational, status or ostentatious 
consumption (Veblen, 1899; Bourdieu 1979). The aspiration to consume goods that cannot be acquired for financial reasons becomes a new, attractive argument:

“Our company's mission: to enable internet users to hire objects that they would otherwise have been unable to afford (technology, luxury...) », extract from the site E-loue ${ }^{\mathrm{xvi}}$.

"Glasses for hire, looking for an owner for the evening to look fantastic together. From a selection of 60 models of fashionable sunglasses or corrective glasses lunettes made by the most famous fashion designers as well as upcoming stars, fashion chameleons looking for accessories can hire the object they desire at a very affordable price!" extract from the site La Fabrique de lunettes ${ }^{\text {xvii }}$.

This ability to access previously unaffordable goods strengthens the trend for individuals to aspire to higher (more expensive) things, and for consumer desires to be stretched upwards towards reference groups whose purchasing power is extremely high. This leads to the creation of a national luxury culture (Bardhi et al, 2012). Surprisingly, it also allows less wealthy people to aspire to higher social status, giving them access to new upscale, high-status objects. As such it develops the social side of sustainable development via an egalitarian social phenomenon, but one that is not particularly in line with the environmental approach.

It also contributes to the development of multiple identity-shaping projects by consumers. Car sharing sites, for example enable consumers to try different models of car, liberating them from the constraints of ownership and giving them access to greater freedom and a more flexible lifestyle.

\section{DISCUSSION}

Our findings confirm the fact that collaborative consumption, conceptually rooted in ecological principles, is indeed developing new practices based on a second life for products (second-hand purchases, rental, recycling, bartering, reselling) and on sharing purchases (loans, giving, rental, shared product pools). It is proposed by the websites as an approach that is more respectful of the environment, and is genuinely perceived as such by the most eco-friendly consumers.

But overall it is related to a desire to develop social links, and is a vector for social equality more than an ecological, altruistic model. It gives certain types of people access to certain goods from which they were previously excluded, and the emergence of new forms of solidarity favoring neighborliness and conviviality. It can thus become the best way to develop the social aspect of sustainable consumption, which is often limited to its environmental dimension (Peattie and Collins, 2009, Cohen, 2007).

We also show that collaborative consumption is capable of generating a more general sustainable model. By fundamentally modifying the relations between individuals and consumer goods, it establishes more collective and probably more lasting sustainable behaviors. In a way, it helps to remove the mystique attached to the idea of ownership, and gives more value to access, historically considered as an inferior, precarious, transitory form of consumption, restricting individual freedom (Bardhi \& Eckart, 2012). By advocating the purchase of the use of a good rather than the good itself, it begins the process by which individuals will gradually abandon the values associated with materialism. It also brings back into fashion the idea of sharing, which is close to that of giving, or that of exchanging merchandize (Belk (2007) in the shared public domain; this develops a less materialistic relationship with objects, which is more altruistic and pro-social. Collaborative consumption can thus become a neighborly rather than a materialistic act, and can create social links and favor feelings of solidarity.

Moreover, we see that consumer experiences is considered by some consumers as a means of resistance "through consumption" to the traditional market system, but that it can also be part of a more general, radical form of resistance "to consumption," in line with movements in favor of voluntary simplicity and negative growth (Kates \& Belk, 2001).

At the same time this work has brought to light a paradox. Far from moving away from utilitarian expectations in favor of humanitarian or existential values, the study shows that collaborative consumption responds 
to financial expectations much more than it does to ecological concerns. It clearly echoes the opportunistic, financial motivations of smart shoppers and individuals who see their purchasing power falling. On the other hand it allows buyers to take back control of consumption by providing a broader range of possibilities for budget management. In this way it can contribute to better consumption or even less consumption, which are themselves sustainable objectives.

But the other facet of collaborative consumption remains its capacity to position itself as a vector for multiple, constantly renewed consumption. In this way it becomes a means to hyper-consume by accelerating the desire for consumption (Belk and $a l$, 2003, Denegri-Knott, 2011) and by enabling consumers to experience original, recreational emotions. Such experiences fulfill the desire for flexibility, ease and practicality, and helps consumers to shape the new identity they are looking for. Thus, from the perspective of identity and recreation, collaborative consumption contributes more to hyper-consumption than to sustainability.

Furthermore, when it is combined with the desire for financial gain, this acceleration of the desire to consume can lead the consumer to reinvest the savings made in other expenses. Like the rebound effect linked to frugality that Schneider (2009) underlines, the decrease in spending made possible by shared use services can generate the transfer of consumption practices to other products. The ecological effects induced by a fall in the number of products manufactures and the replacement of the sale of goods by the shared sale of use might be wiped out by this transfer of spending, possibly to material products that cause pollution.

Finally, our analysis of the consumption blogs and sales arguments used by the sites reveals motivations that are both collective and individual, based on changing boundaries between the self/others/objects, and consequently the planet; and utilitarian, hedonic motivations focusing on the self. These two facets are not mutually exclusive; on the contrary they tend to combine and merge in consumer discourses. Attitudes to objects also become an important vector, and depending on the individual can be interpreted as a desire for experiential overconsumption or an aspiration to consume and possess less. The sustainable foundations of collaborative consumption are thus directly integrated, either visibly or not depending on the individual, practices and the website.

In the light of these findings, we now summarize the profiles of consumers using these collaborative sites and their link to sustainable consumption, as identified by our research.

Table 3: Consumers Segmentation Proposal

\begin{tabular}{ll}
\hline Values & \multicolumn{1}{c}{ Behaviors } \\
\hline Smart shoppers & $\begin{array}{l}\text { Look to control their spending and their budget; can contribute to de-consumerism for financial } \\
\text { reasons. }\end{array}$ \\
\hline Altruistic humanists & $\begin{array}{l}\text { Look for social links, are sensitive to humanitarian causes; look for services that facilitate contact and } \\
\text { getting to know others, are prepared to defend social consumerism. }\end{array}$ \\
\hline Pleasure seekers & $\begin{array}{l}\text { Look for entertainment and pleasure via the new forms of collaborative consumption; they get } \\
\text { fulfillment by consuming differently, in a fun, interactive, creative way, without primarily aiming at } \\
\text { moderation }\end{array}$ \\
\hline Alternative consumers & $\begin{array}{l}\text { Look to oppose the dominant market system; they defend alternative ways of relating to property and } \\
\text { objects. They have a more radical, militant and demanding attitude to the sustainable contents of } \\
\text { collaborative sites. }\end{array}$ \\
\hline Postmodernists & $\begin{array}{l}\text { Sensitive to the value of emotional links as much as to utilitarian value; post-modern consumers used } \\
\text { to steering between opposing sentiments; can contribute to sustainable consumption via their } \\
\text { sensitivity towards spending if and only if social links are guaranteed by the site, enabling them to } \\
\text { share with others. }\end{array}$ \\
\hline $\begin{array}{l}\text { Bourgeois Bohemians } \\
\text { (hipsters) }\end{array}$ & $\begin{array}{l}\text { Sympathetic to rupture discourses and opposition to the system, despite at the same time being over- } \\
\text { consumers of innovative, esthetic products and services that give them the status of early-adopters or } \\
\text { unusual individuals; use collaborative consumption to be different from the population as a whole. }\end{array}$ \\
\hline
\end{tabular}

\section{MANAGERIAL IMPLICATIONS}

The identification of these six consumer segments allows us to define several possible orientations for managers of collaborative sites. The positioning of the site should, in the classical way, respond to the expectations of the firm's target customers. Our study reveals that whilst on the consumer side there is an identifiable diversity of 
expectations, the discourses of the sites are blurred by general promises that prevent them from distinguishing themselves clearly from other collaborative sites, as demonstrated by sites such as Lokeo, Mon Joujou, Buzzcar, Zipcar, Je loue Mon camping car, Homelink, Guest To Guest...

The ideology or social vision of the firm must be clearly reflected in the discourse of the collaborative site and characterized in the way the site functions, if it is to impact consumer practices effectively. The site's (visual and verbal) discourse, its ergonomics and technological innovation must serve to reinforce the values that consumers hold dear if it hopes to gain the support, create community feeling and thus, in the long-term, monetization.

The interest of this study is that it indicates that there are at least six possible positions for brands to adopt at the junction between sustainability and collaborative consumption : 1/ utilitarian: supporting sustainability via collaborative consumption must flatter the wise-shopper with an objective promise (choice, price, increased product life expectation,...) ; $2 /$ existential: supporting sustainability via collaborative consumption involves connecting consumers in the common interest, with a symbolic promise (live better together, positive moral values,...) ; 3/ militant: supporting sustainability via collaborative consumption, means raising the profile of alternative consumerists with a promise to change practices (give the facts, educate about alternatives to dominant models, create the conditions for another model for economic and social development, partnerships with NGOs, expert reports on sustainable development); 4/ hedonic: supporting sustainability via collaborative consumption can be a pleasure, with a techno-fun message (videos, games, less text more sensations, particularly aesthetic ones); finally two other positions are extensions of the principal ones 5/ postmodern: sustainable development via collaborative consumption advocates a fair balance between economic and social progress with a 'win-win' promise (rational examples in terms of practicality and solidarity or sharing); 6/ retro-techno : where sustainability via collaborative consumption celebrates the originality of revisiting former practices with a resolutely new approach, where consuming against the tide is the guiding principle (tips and tricks, originality and unexpected concepts, ...).

Beyond the need to adapt discourses and strategies to the values and expectations of these segments, our findings demonstrate that the social and ecological competencies of the sites are pre-conditions for the business model. Thus, social aspects, which are clearly perceived and expected, must be reinforced and diversified. For example, territoriality and proximity could be stressed by creating local, macro-social services (sustainable mobility, sustainable housing, sustainable education ...), or services linked to local actors, history, traditions or practices. The range of products on offer could be widened to include new peer-to-peer services, based on solidarity, social integration (skills exchange, voluntary assistance, self-help, parties and celebrations, launch of social currency, development of awareness concerning micro-credit...), expertise (advice, training), crowdsourcing or by highlighting other forms of sharing (for example sharing gardens, or sharing tips and tricks). Similarly the ecological dimension, which is not a particularly significant motivation but is often a side-effect, needs improvement. Thus, site operators could be proactive in developing their product range and selection by giving them tangible ecological characteristics. They could highlight eco-designed products and services, organize their after sales service and repairs in a structured, visible way, underline precise societal information about their products (social and ecological product traceability, product origin). All this will enable them to develop an image rooted in sustainability thanks to arguments such as shared use, use intensity, extended product lifecycle, social progress, the return of local products and so on.

Using these approaches allying financial, experiential, hedonic, social and ecological benefits, and by accentuating its discourse on "consuming differently," collaborative consumption can establish itself as a broadlybased, sustainable, new model.

\section{CONCLUSION}

In this article, we analyze the sense given to collaborative consumption through the prism of sustainability. Undeniably, this model contributes to democratize product use rather than possession, and enables consumers to experiment with this transition from ownership to access and sharing by offering them new individual and social relationships to objects. Thus it gives the act of consuming traditional positive values such as simplicity, tranquility, flexibility, a reduction in perceived risk and choice; and these are combined with new values such as living together, originality, sharing, product reuse and so on. 
Collaborative consumption enables consumers to escape from traditional economic logics. It shows the growing independence of consumers, their desire to become active in the consumption process and their growing mistrust of pre-established models. The new trend of sharing also fulfills a new desire to participate, to "co-produce together" and to reduce the mediation between production and consumption.

But it also reveals the dual nature of consumers who want to be both outside and part of the system, by reinforcing their eagerness to experience emotion and fun, and by helping them to optimize their purchasing power.

Collaborative consumption feeds the debate over the key question for sustainable consumption: does sustainable development require us to consume differently or to consume less (Jackson \& Michaelis, 2003)?

Our findings reveal that collaborative consumption falls primarily within the scope of consumer schemas that put the accent on "consuming differently. But by stressing practical and financial benefits, by responding effectively to the need for new social relations and by developing products and services rooted in ecological practices, the players on this market have all the means at their disposal to move towards proposals promoting the idea of consuming less or better. The six possible ways of combining sustainability and collaborative consumption identified in this article are possibilities for managers to work on, so as to respond in a less monolithic manner to the broad range of collaborative consumer expectations.

\section{AUTHOR INFORMATION}

Anne-Sophie Binninger is Full Professor of Marketing at NEOMA Business School, France. Her research is focused on the socio-cultural trends affecting Marketing, Branding and Retailing, and tackles especially sustainability and consumption. Anne-Sophie's worked appeared in international academic journals including International Journal of Retail and Distribution Management, Journal of Macromarketing, Journal of Food Products Marketing, Management International as well as in French academic journals and collective or individual books. E-mail: anne-sophie.binninger@neoma-bs.fr (Contact Author)

Nacima Ourahmoune is Associate Professor of Marketing at NEOMA Business School, France. Her academic research tackles how social transformations impact marketing and consumption phenomena. Nacima's work has been presented in over 40 international conferences, and appeared in Marketing Theory, Journal of Macromarketing, Journal of Consumer Behavior, Advances in Consumer Research, and in several books.

E-mail: nacima.ourahmoune@ neoma-bs.fr

Isabelle Robert is an Assistant Professor of Marketing and Corporate Social Responsibility at Univ North of France. Her research interests focus on sustainable consumption, sustainable development and social corporate responsibility. Her work appeared in various journals Journal of Macromarketing, Décisions Marketing, Revue Management et Avenir, Revue Sciences de gestion...). Isabelle participated in editing the book "50 fiches sur le marketing durable” (2010) in Breal Editions, Paris. E-mail: isabelle.robert-2@univ-lille2.fr

\section{REFERENCES}

Albinsson P. A. and Perera B. Y. (2012). Alternative marketplaces in the $21^{\text {st }}$ century: Building community through sharing events. Journal of consumer Behaviour, 11, 303-315.

Bardhi F. and Eckhardt G.M. (2012). Access-Based Consumption: The Case of car sharing. Journal of Consumer Research, 39, 4, 881-898.

Bardhi F., Eckhardt G.M and Arnould E.J. (2012). Liquid Relationship to Possessions. Journal of Consumer Research, 39, 510-529.

Bauman, Z. (2000), Liquid Modernity, Cambridge: Polity.

Bauman, Z. (2007), Liquid Times: Living in an Age of Uncertainty, Cambridge: Polity.

Belk, R.W. (1988). Possessions and the Extended Self. Journal of Consumer Research, 15, 139-68.

Belk R. W. (2010). Sharing. Journal of Consumer Research, 35, 712-734.

Bell D. (1976), Welcome to the post-industrial society, Physics today, 46-49

Botsman, R., \& Rogers, R. (2010). Beyond Zipcar: Collaborative consumption. Harvard Business Review, 88(10), 
30 .

Bostman R. and Rogers R. (2011). What's Mine is Yours. How Collaborative Consumption is Changing The Way We Live. London, Ed Collins.

Bourdieu P. (1979). La distinction, critique sociale du jugement. Paris, Les éditions de Minuit.

Chen Y. (2009). Possession and Access: Consumer Desires and Value Perceptions Regarding Contemporary Art Collection and Exhibit Visits. Journal of Consumer Research, 35, 925-40.

Cohen, M. J. (2007). Consumer credit, household financial management and sustainable consumption. International Journal of Consumer Studies, 31, 57-65.

Connolly J. and Prothero A. (2003). Sustainable consumption: consumption, consumers and the commodity discourse. Consumption Markets \& Culture, 6:4, 275-291.

Denegri-Knott. J (2011). "Have It Now!”: Ebay and the Acceleration of Consumer Desire, European Advances in Consumer Reseach, 9, 373-379.

Dobscha S. (1998). The Lived Experience of Consumer Rebellion Against Marketing, Advances in Consumer Research, 25, 91-97.

European Commission. (2008). Eurobarometer, Attitudes of European citizens towards the environment, Report 295, wage 68.2, March 2008

Felson M. and Spaeth J. L. (1978). Community structure and collaborative consumption. A routine activity Approach, The American Behavioral Scientist, 21, 4, 614-624.

Flyvbjerg, B., (1991), "Sustaining Non-Rationalized Practices: Body-Mind, Power, and Situational Ethics. An Interview with Hubert and Stuart Dreyfus." Praxis International, vol. 11, no. 1, April 1991, pp. 93-113.

Flyvbjerg, B., (2006), "Five Misunderstandings About Case-Study Research," Qualitative Inquiry, vol. 12, no. 2, April, pp. 219-245.

Gansky. L. (2010). The Mesh: Why the future of Business is sharing. New York, Penguin.

Giesler M. (2006). Consumer Gift Systems. Journal of Consumer Research, 33. 283-290.

Gleim M.R, Smith J, F, Andrewsb D. and Cronin Jr J.J. (2013). Against the Green: A Multi-method Examination of the Barriers to Green Consumption. Journal of Retailing, 89 (1), 44-61.

Godbout, J. T. (1992). L'esprit du don [The gift's spirit]. Paris: La Decouverte..

Jackson, T. and Michaelis, L. (2003). Policies for Sustainable Consumption. Sustainable Development Commission. London.

Kates S.M. and Belk R.W. (2001). The meanings of Lesbians and Gay Pride day: resistance through consumption and resistance to consumption. Journal of Contemporary Ethnography. 30, 4, 392-429.

Kilbourne, W. E. (2010). Facing the challenge of sustainability in a changing world: An introduction to the special issue. Journal of Macromarketing, 30(2), 109-111.

Kleine S.S., Kleine R.E. and Allen C.T. (1995). How Is a Possession 'Me" or 'Not Me'? Characterizing Types and an Antecedent of Material Possession Attachment. Journal of Consumer Research, 22, 327-343.

Kotler, P. (2011). Reinventing marketing to manage the environmental imperative. Journal of Marketing, 75(4), $132-135$.

Kozinets, R. V. (2002). The field behind the screen: using netnography for marketing research in online communities. Journal of marketing research, 39(1), 61-72.

Kozinets, R. V. (2010). Netnography: Doing ethnographic research online. Sage Publications.

Lovelock C. et Gummesson E. (2004), Whither services marketing? In search of a new paradigm and fresh perspectives, Journal of Service Research, 7, 1, 20-41.

Lipovetsky G. (2006). Le bonheur paradoxal. Paris, Ed Gallimard.

Lincoln Y.S., \&t Guba E.G. (1985). Naturalistic Inquiry. Beverly Hills, Sage Publications.

McDonagh, Pierre, Susan Dobscha, and Andrea Prothero (2012), "Sustainable Consumption and Production: Challenges for Transformative Consumer Research," in Transformative Consumer Research for Personal and Collective Well Being: Reviews and Frontiers, David Glen Mick, Simone Pettigrew, Cornelia Pechmann, and Julie L. Ozanne, eds. Abingdon, UK: Routledge, 263-277.

Markkula A. and Moisander J. K. (2012). Consumers and discursive confusion over sustainable development. Journal of Consumer Policy, 35, 105-125.

Mont O. (2002), Clarifying the concept of product-service system, Journal of Cleaner Production, 10, 3, 237-245.

Ostrom. E. (2010). La gouvernance des biens communs : Pour une nouvelle approche des ressources naturelles. Ed De Boeck.

Ourahmoune, N., \& Özçağlar-Toulouse, N. (2012). Exogamous weddings and fashion in a rising consumer culture: 
Kabyle minority dynamics of structure and agency. Marketing Theory, 1470593111424182.

Ozanne L. and Ozanne J. (2011). A child's Right to Play: The Social Construction of Civic Virtues in Toy Library. Journal of Public Policy and Marketing, 30, 2, 264-278.

Peattie K. and Collins A. (2009). Guest editorial: perspectives on sustainable consumption. International Journal of Consumer Studies, 33, 107-112.

Prothero, A. Dobscha, S., Freund, J., Kilbourne, W., Luchs, M. G., Ozanne, L. K. and Thogersen, J. (2011). Sustainable Consumption: Opportunities for Consumer Research and Public Policy. Journal of Public Policy \& Marketing, 30 (1), 31-38.

Reisch, L. (1998). Sustainable consumption: Three questions about a fuzzy concept. Working paper, Research Group "Consumption Environment and Culture", Department of Marketing, Copenhagen Business School, Denmark.

Richins M.L. (1994). Special Possessions and the Expression of Material Values. Journal of Consumer Research, $21,522-533$.

Rifkin J. (2000). L'âge de l'accès. Paris, Ed La Découverte

Schneider F. (2009). Sur l'importance de la décroissance des capacités de production et de consommation dans le Nord Global pour éviter l'Effet Rebond. In Mylondo (Ed), La décroissance économique pour la soutenabilité écologique et l'équité sociale, Collection Ecologica, Editions du Croquant, 197-214.

Scholl G. (2006). Product Service Systems: Taking a Functional and a Symbolic Perspective on Usership. In Maj Munch Andersen and Arnold Tukker (Ed), Perspectives on Radical Changes to Sustainable Consumption and Production (SCP), Workshop of the Sustainable Consumption Research Exchange (SCORE!) Network, 20 and 21April, Copenhagen, Denmark, 25-44.

Sheth J. N., Sethia N. K, Srinivas S. (2011). Mindful consumption: A customer-centric approach to sustainability. Journal of the Academy of Marketing Science, 39, 21-39.

Spais, G.S. (2011). An activity system as a behavioristic framework for the elaboration of promotion techniques. Journal of Applied Business Research, 27(3), 9-32.

Veblen T. (1899). The theory of the leisure class. New York: Modern Library.

\section{Additional Websites}

${ }^{1}$ http://www.ilokyou.com consulted on 14 October 2013

1 http://www.trocdepresse.com consulted 8 April 2014

1 http://www.monjoujou.com, consulted 25 January 2013

${ }^{1} \mathrm{http}: / /$ www.homelink.fr/, consulted on 12 June 2014

${ }^{1}$ https://www.streetclub.co.uk, consulted on 2 March 2013

1 http://fr.freecycle.org/accueil, consulted on 10 June 2014

${ }^{1}$ http://www.laruchequiditoui.fr, consulted on 10 February 2014

1 http://www.yooneed.com/, consulted on 22 May 2014

1 http://www.lokeo.fr, consulted on 22 April 2013

1 http://www.monjoujou.com

1 https://www.jelouemoncampingcar.com, consulted on 19 December 2013

1 https://www.e-loue.com, consulted on 23 March 2013

1 http://www.ecojouet.fr, consulted on 18 March 2013

1 http://www.monjoujou.com

1 http://www.videdressing.com, consulted 17 April 2014

1 https://www.e-loue.com, consulted 25 April 2013

${ }^{1}$ http://www.lafabriquedelunettes.fr, consulted 2 March 2013 
NOTES 